\title{
Crosskey on the Constitution: An Essay-Review
}

\author{
James A. Durham*
}

$\mathrm{O}^{\mathrm{N}}$ NE HUNDRED AND STXTY-FIVE YEARS after its ratification, the Constitution of the United States has become the subject of a great book. The reference applies to the recently published two-volume work entitled Politics and the Constitution in the History of the United States, ${ }^{1}$ by William Winslow Crosskey, a member of the law faculty at the University of Chicago.

Some people will call Crosskey's book vicious, because it proposes a construction of the Constitution which they fear; others will call it an irreverent work, for by implication it criticises those they revere; still others will damn it as a corrupting influence, for it challenges many of the orthodoxies of our legal and political system. Unquestionably it is the most revolutionary commentary ever published on the Constitution.

Yet these very controversies are bound to contribute to the acceptance of the construction these volumes expound. When examined, the legal structure which unfolds not only is convincing, but in addition is most compatible with the present political economy of the United States. Logic, evidence, methodology and economic interest are combined so effectively that a break with currently accepted concepts about the Constitution seems almost assured within a few years.

\section{Introduction}

The novelty of Crosskey's work is apparent from a niere summary of his position: The Constitution established a national government with general and comprehensive powers, except where limited; the directive power was placed in the Congress, which was given all the legislative power granted to the national government by the Constitution; the purpose of the specific enumerations of legislative powers in Article 1, Section 8, was largely to erase any possibility that these powers could be asserted as executive powers, as the standing law. then permitted; other specific enumerations were made to insure that the states could not claim exclusive power, to indicate the changes made from the Articles of Confederation, and to emphasize the main purposes of the new national government.

Similarly, in Article III the establishment of the Supreme Court and the enumeration of the judicial power was necessary to make the judiciary

* Member of the Bars of Indiana, Kentucky and the Supreme Court of the United States.

1 Chicago, University of Chicago Press, April 1953. ix, 1410pp. $\$ 20.00$. 
independent of the executive, in contrast to existing English institutions, and to prevent either executive or legislative interference in cases where the Supreme Court was given juridical supremacy.

The enumeration of the principal executive function- " [to] take care that the Laws be faithfully executed"-was necessitated by the Articles, since under the latter Congress and the states had jurisdiction over law enforcement. In addition, this ministerial definition of the President's principal duty, plus the enumeration of the exclusive powers arising out of his designation as Commander in Chief and grantor of reprieves and pardons, effectively erased noost of the traditional executive dispensing power. Under the new arrangement of legal institutions, except for the ability to conduct foreign policy and recommend legislation, the executive was to be merely the agent of the Congress in the administration of the laws enacted pursuant to the general legislative authority. As if to goad it into an acceptance of the major responsibility for governing, Crosskey dedicates his work to the Congress itself in these words:

\author{
To the \\ Congress of the United States \\ in the Hope That It May Be Led to Claim \\ and Exercise for the Common Good of the Country \\ the Powers Justly Belonging to It \\ Under the Constitution
}

\title{
Basic Valuations
}

At the outset, Crosskey brusquely sets forth his general conclusions in an introductory chapter entitled "Our Unknown Constitution." Unquestionably it must have been this chapter, taken together with the concluding one, which led Carl Brent Swisher to twice characterize the work as a "lawyer's brief," for it is incredibly sharp and argumentative. Here Crosskey argues that the misconceptions he finds in the orthodox interpretation of the Constitution " . . . are products, in the main, of the many attempts that have been inade to distort the Constitution to serve some political end." Other cases of forgotten meaning, he explains, are due to "prolonged disuse" of 18th century meanings; to changed usage of certain key words in the Constitution (e.g., "among the several states" in the commerce clause); and a change in basic political ideas which is generally not assumed to have occurred (e.g., development of the concept of "three equal branches" of Government from French writers and the interests of the South, in contrast to the desire of the Constitution's writers to establish legislative supremacy).

The first chapter also contains a direct attack upon James Madison,

${ }^{2}$ Evolution of a Document, The Saturday Review, April 4, 1953, pp. 33-34. 
upon the reliability of his 1840 papers, and upon the lawyers and historians who have relied upon them as the Bible of Constitutional construction. The related concluding chapter entitled "Solutions and Problems" (chapter 33) also contains a vigorous attack upon legal scholarship, which Crosskey feels has tended merely to reflect misconceptions accepted by the court, with the exception of due process. Throughout, Crosskey convincingly argues that the Jeffersonians were by no means pure scholars but had an axe to grind. Not only was it necessary for them to capture the Presidency to protect slavery, but in addition it was necessary to limit the powers of Congress, accomplished by the building of the states rights tradition. Both lawyers and historians have on occasion expressed some reservation about the use of Madison's private letters published in 1840 to explain a 1787 Constitution. There is a considerable body of law to the effect that only contemporaneously published public history may be employed to indicate Congressional intention.

As has been implied, the initial chapter reflects the biases of the author. Crosskey has a tremendous affection for the common law as it came to us from England, and he resents the use of the Constitution to divorce us from that great doctrine in matters of public concern. He has an abiding pride and affection for the American leadership of 1787, particularly for those among it who consistently stood by the national government, and he has a passionate hatred of slavery that permeates the entire work. Crosskey's evidence rather effectively demonstrates that it was slavery almost alone which brought about the misconceptions he attacks. For without slavery to defend, most of the incentive to shift the meaning to be given to the Constitution would have been missing.

Although Crosskey does not clearly label his biases and tell the reader how they developed, the first chapter does raise a warning signal that the author is mounting a frontal attack. There is no soft soap or clever semantics to lull the reader imto thimking that Crosskey is only moving a few bricks from the accepted Constitutional structure. Instead, the wrecker demolishes and a new building arises. Were this chapter modeled on Myrdal's great statement on Methods of Mitigating Biases in Social Science ${ }^{3}$ it would have been less passionate, but nonetheless, social scientists will recognize and applaud Crosskey's first chapter for effectively disrobing the heart of the author. ${ }^{4}$

\footnotetext{
3 Myrdal, AN AMirerican Dileama, 1041-1045 (1944).

4 Myrdal writes (Id., at 1943): "Biases in research are much deeper seated than in the formulation of avowedly practical conclusions ... .

"The valuations will, when driven underground, hinder observation and inference from becoming truly objective. This can be avoided only by making the valuations explicit. There is no other device for excluding biases in social sciences than to face the valuations and to introduce them as explicitly stated, specific, and sufficiently concretized value premises . . . Only in this way does social engineering, as an "advanced branch of social research, become a rational discipline under full scientific control."
} 
Some future critics of Crosskey will concern themselves with discovering how his biases developed. Normally one would not expect an upstate New Yorker, the product of Yale's college and law school, to lead an assault of this character. Yet unquestionably Crosskey's thinking about the Constitution began long before the 15 year period of research given over to the volumes. Significantly, Crosskey was serving as clerk to Chief Justice Taft when Myers v. United States, ${ }^{5}$ contaiming the comprehensive statement on the Presidential removal power, became part of legal literature. Then came nearly eight years of respectable experience with Davis, Polk, Wardwell, Gardiner and Reed; with Milbank, Tweed, Hope and Webb; and with an industrial corporation, all in New York City. It is hard to believe that this period in his career had much bearing on his views in Politics and the Constitution.

In his final chapter the author indicates that additional volumes are to come, which will largely be devoted to the economic, legal, and political history of the 18th century. Apparently the central theme of these volumes will be an attempt to explain just how the Constitution, as Crosskey views it, could be so acceptable in 1787, and yet be rejected 25 to 40 years later by the leading political figures of the Republic and the Supreme Court. In an appendix to the additional volume or volumes it would be fortunate if Crosskey were to set forth expressly his own understanding of his biases, valuations, and their formulation.

\section{The Commerce Power}

Crosskey's 15 years of research on the Constitution began with an attempt to write a convincing article on the commerce power. Since this experience opened the door to further speculation and new evidence about other portions of the Constitution, it is not surprising that Part I, consisting of eight chapters (chapters 2 through 9 ), should be devoted to this subject. It is here that he attacks the madequacies of the "interstate" theory of the commerce power; it is here that he turns back to the 18th century word usage to demonstrate that the word "among" (the several states) was not synonymous with "between" (the several states); and it is in these chapters that he develops the comprehensive 18th Century character of the concept to regulate commerce. Contrary to the usual assumptions that "commerce". defined only a narrow area of trading, Crosskey's evidence points to the conclusion that all gainful activity (including agriculture) was intended to be included in the definition of commerce.

Such a comprehensive definition, if accepted, will force those who oppose the development of a stronger national government to appeal to

5272 U. S. 52 (1926). 
voters instead of to judges. However, it may well be that so-called "conservative" economic groups within the community may cone to utilize Crosskey, for the time and money spent in drafting and lobbying so-called "uniform" coinnercial laws through individual state legislatures has been most unproductive. Surely the present day Supreme Court would hesitate to strike down a Federal negotiable instruments law, a statute which is more likely to flow from the present political arrangement in Washington than an act establishing a one dollar per hour minimum wage for every worker in the nation, irrespective of einployer or task perforned. Yet the former decision would become a strong precedent for upholding the latter statute.

\section{Related Commercial Provisions}

Part II of the work (chapters 10 through 12) is devoted to the interrelationships between the commerce clause and the prohibitions of Section 10, Article I, against state enactnent of (a) laws placing duties on imports and exports, (b) ex post facto laws, and (c) laws impairing the obligation of contracts. The short of it is that Crosskey finds that these prohibitions upon state action, particularly the latter, support his comprehensive construction of the commerce clause. His evidence indicates that state taxes on interstate commerce were one of the mischiefs which the imports-exports prohibition was intended to cure. This view rebuts the conclusion of Woodruff v. Parham ${ }^{6}$ that the prohibition on state action extends ouly to "foreign commerce," which in turn supports the present "imterstate" theory of the Congressional power over commerce.

With respect to the ex post facto prohibitions (against both state and national governments), the author argues they were intended to apply to civil as well as criminal legislation. Here he takes issue with Calder v. Bull ${ }^{\top}$ and supports Justice Johnson's unsuccessful attempt to reverse it in two subsequent cases. ${ }^{8}$ Crosskey's position on the ex post facto prohibitions is significant in the area of commercial regulation, because it inakes more meaningful his construction of the contracts clause, which in turn has a bearing on the completeness of the national power over commerce. The author's position is that the contract clause prevents the state from impairing any contracts, whether or not previously formed. Thus instead of presenting a prohibition against retrospective contract regulation, which is the accepted view, the contracts clause becomes a vehicle by which the states are excluded from inpairing any contracts whatsoever. Instead of

88 Wall. 123 (1868).

73 Dall. 385 (1798).

8 Ogden v. Saunders, 12 Wheat. 213, 286 (1827); Satterlee v. Matthewson, 2 Pet. 380, 416 (1829). 
creating any other kind of ex post facto prohibition, Crosskey interprets the clause so as to give Congress exclusive authority to regulate contracts, there being no contracts clause in Section 9, Article I, the section containing prohibitions against Congressional action. ${ }^{9}$

\section{The Legislative Enumerations}

Part III of the work (chapters 13 through 22) is entitled "A Unitary View of the National Governing Powers." The methodology of this portion of the work throws considerable light upon Crosskey's subsequent treatinent of the 14th Anendinent (chapters 31 and 32) and suggests the inethodology which the author can be anticipated to follow in his subsequent volumes. At the outset he explores the accepted rules of legal interpretation which prevailed in the 18 th century, the scheme of Constitutional draftsmanship, and the scope of the common law in 1787. From such significant sources as Blackstone he gives new meaning and emphasis to such things as the Preamble (now largely disregarded both with respect to the construction of statutes as well as constitutions), the congressional and judicial enumerations, and the concept of negative implications. To the extent that he places greatest emphasis upon the document itself, its expressed purposes, and the other internal aids to construction, Crosskey's approach is similar to Justice Jackson's emphasis in the construction of statutes. The author does rely upon some external aids to construction, as these are sometimes inextricably intertwined with internal aids, but the greater portion of the external evidence supporting the position taken presumably will follow in subsequent volumes.

In view of the now prevalent tendency to rely upon external aids in the construction of statutes, sometimes to the exclusion of internal aids, many people are likely to reserve judgment on Crosskey until the publication of his additional evidence. From this external evidence, Crosskey asserts in chapter 33, " . . . it will be found that weight, not doubt, has been added to the conclusions, as to the true view of the Constitution itself, which have been presented in the foregoing pages."10

Perhaps the most fascinating chapters of the work are those dealing with the general legislative power of Congress, the influence of the standing law (particularly the royal prerogative) as necessitating legislative, executive and judicial enumerations, and the impact of the 10th Amendment upon the powers of Congress (chapters 14,15,16, 17 and 22). The assump-

9 The chapters on the ex post facto prohibitions and the contracts clause closely follow Crosskey's views which appeared in his only two appearances in periodic literature. See The True Meaning of the Constitutional Prohibition of Ex Post Facto Laws, 14 U. of Chi. L. Rev. 539 (1947) and his review of Wright, The Contracts Clause of the Constitution, 47 J. Pol. Econ. 578 (1939).

102 Crosskey, at 1175. 
tions underlying Justice Roberts' opinion in United States v. Butler, ${ }^{11}$ are laid bare to the extent that this expression of exclusive state power will probably be totally discredited. Both the Madisonian and Hamiltonian limitations on the common defense and general welfare clause are rejected in favor of a comprehensive affirmative power.

Carefully Crosskey indicates which of the enumerated powers were given to Congress lest they be assumed to remain with the states (as under the Articles of Confederation), which of the enumerated powers were given the Congress lest they be assumed to remain with the executive (as under Blackstone's explanation of the royal prerogative) and which of the enumerated powers were given to Congress to accomplish reforms in the standing law.

\section{The Executive Function}

Crosskey indicates that the enumeration of faithful execution of the laws by the President was designed to place upon him a duty of law enforcement (thereby eliminating the surviving executive dispensing power referred to in Blackstone), and to assure that the states could not assume this function (as under the Articles). Had it been available, this work would have been useful to corporate counsel John W. Davis in the recent case of The Youngstown Sheet and Tube Co., et al. v. Sawyer. ${ }^{12}$ Besides strictly worded power to reprieve and pardon, Crosskey says that " . . . it follows that no other power of dispensing with 'the Laws,' or the execution of 'the Laws,' or of proceeding outside them, whether state or national, written or unwritten, can possibly belong to an American President." ${ }^{\text {"13 }}$ It is interesting that both the opinions of Justices Black and Douglas in the Youngstown case enunciated the same principle in unmistakable terms. ${ }^{14}$

\section{The Judicial Article and Congressional Power}

The author also finds support in the Judiciary Article for a general legislative power in Congress. This analysis appears in chapters 18 through 22, and also spills over into Part IV of the work.

As heretofore indicated, Crosskey believes that one of the principal purposes of establishing the Supreme Court was to prevent a strong execu-

11297 U. S. 1 (1936).

12343 U. S. 579 (1952).

131 Crosskex, at 436.

14 Justice Black: "Nor can the seizure order be sustained because of the several constitutional provisions that grant executive power to the President. In the framework of our Constitution, the President's power to see that the laws are faithfully executed refutes the idea that he is to be a lawmaker." (343 U. S. 579, 587.)

Justice Douglas: “. . . The power to recommend legislation, granted to the President, serves only to emphasize that it is his function to recommend and that it is the function of the Congress to legislate. . . But, as Mr. Justice Black and Mr. Justice Frankfurter pointed out, the power to execute the laws starts and ends with the laws Congress has enacted." (Id. at 632.) 
tive from asserting that the courts were subject to his will. Although by 1787 Parliament had secured a large measure of control over the judiciary through legislation preventing the removal of certain judges, Crosskey notes that Blackstone still listed the dispensation of justice as an executive function and, even more significantly, that many of the colonial disputes had been with judges responsible to the Crown or its agents. This analysis is supported by the fact that Article III left it to Congress to establish such inferior courts as it saw fit, and also provided that Congress should have the power to prescribe rules and regnlations with respect to the Court's appellate jurisdiction. Coupled with the authority of the Senate to reject Presidential nominations for the Supreme Court (Section 2, Article II), this relationship certainly does not suggest that the Supreme Court owes its existence to any fear of legislative control of the judiciary.

Crosskey also employs the Judicial "enumeration" to buttress the general legislative authority of Congress. Thus the judicial power extends ". . . to all Cases, in Law and Equity, arising under this Constitution, the Laws of the United States, and Treaties made, or which shall be made, under their Authority; . . . "The crucial question becomes what were "the Laws of the United States" in 1787? Presumably this included statutes passed under the Articles, and any new Congressional enactments. However, did it include "the common law"? As is well known, in United States v. Hudson and Goodwin ${ }^{15}$ the Supreme Court first accepted the proposition that "the common law," including the English amendatory statutes of colonial applicability, was not one of "the laws of the United States." Instead it was assumed that each state adopted the common law at the time of its inception. Since the states came into being over the period of a century, there would be several separate "common laws" and no possibility of regarding "the common law" as part of "the Laws of the United States." Since "the common law" of England was then understood to have included the general commercial law, it was of extreme political importance to the South to deny the existence of a nationally accepted common law. If the judicial power did extend to the common law in this comprehensive sense, then Congress could amend it; and if Congress could change the law relating to bills of exchange, who could then say that the general legislative power, the generally assumed power of the legislature to make rnles of decision binding on its courts, plus the commerce power, plus the "necessary and proper" clause (Crosskey's "sweeping" power) were not sufficient to regulate any transactions in human property deemed appropriate by the Congress?

Apart from destroying its judicial supremacy in the long line of cases

157 Cranch 32 (1812). 
from Hudson and Goodwin to Erie v. Tompkins, ${ }^{16}$ Crosskey argues that the demial of a nationally applicable common law made the Supreme Court intellectually incapable of understanding the legislative enumeration, and by the same token led to an unwarranted reliance on the Tenth Amendment. If Crosskey's evidence is correct, the colonies did accept the English common law, including the general commercial law. His most persuasive evidence was the absence of any state reports until 1789 , at which time the preface to the first Connecticut Reports stated that there was no such thing as a "Connecticut common law." It was not until 1847 that the last of the original colonies published reports of state court decisions. This incapacity to absorb the full meaning of the enumeration, Crosskey argues, led to the growing concept of the Tenth Amendment as a linitation on the national power, both legislative and judicial. Instead the author views the so-called "reservation of power" in the Tenth Amendment as an assurance of the perpetuation of concurrent state power, except where the Constitution expressly prohibited state action or placed exclusive jurisdiction in the national government.

\section{The Supreme Court and Consolidation of the National Power}

From the judicial enumeration Crosskey moves logically to a contrast between the Supreme Court's function as it has developed and his view of its intended function. These matters are covered in Part IV of the work (chapters 23 through 26) and is followed in the same Part by three chapters on judicial review (chapters 27 through 29). It is likely that this Part will provoke the greatest amount of discussion among the Bar and the Judiciary.

The short of it is that such cases as United States v. Hudson and Goodwin, ${ }^{17}$ Green v. Neal, ${ }^{18}$ Erie v. Tomkins, ${ }^{19}$ and even Sroift v. Tyson ${ }^{20}$ could not possibly have been decided under Crosskey's construction. His position is that the Constitution provided that the Supreme Court of the United States was to be the head of a umified system for adnninistration of justice, that this was recognized at the outset by political leaders, state courts, and the Supreme Court itself, and that only the slavery institution and the acceptance of Jefferson's aforementioned argument about the nonexistence of a national common law prevented the Supreme Court from asserting its rightful place in the Constitutional system. Crosskey would never place the Supreme Court in a coordinate position with the state courts, as in Swift v. Tyson, and much less would he embrace its subordination to the state courts which appears to be the practical outcome of the Erie doctrine.

\footnotetext{
16304 U. S. 64 (1938).

17 Supra note 15.

186 Pet. 291 (1832).

10 Supra note 16.

2016 Pet. 1 (1842).
} 
With Justice Jackson and Judge Clark still entertaining a healthy skepticisin about the consequences of the Erie case, it should not be long before the Supreme Court will have reason to examine Crosskey's position and evidence on this point. While Erie by itself made a strong appeal to a great many people, including this writer, its logical extension in such cases as West v. American Telephene and Telegraph $\mathrm{Co}^{21}$ and Fidelity Union Trust Co. v. Field ${ }^{22}$ has caused real concern about the whole Erie concept. The feeling is growing that this sort of hodge-podge jurisprudence is unworkable. ${ }^{23}$

In a very real sense the establishment of the Supreme Court as the final arbiter of legal matters contributes, over the long run, to the consolidation of the national power. The development of a uniform common law which Congress could change by statute is but part of the picture. In addition, because of its appellate jurisdiction, the Supreme Court would be in a position to conipel obedience to its precedents. There could be no defiance of the Supreme Court because the failure to follow its precedents would raise a question under the Judiciary Article and supremacy clause of Article VI. In other words, a case involving the meaning of a Supreme Court precedent is a case "arising under the Constitution." This position is buttressed by the fact that Article VI of the Constitution also provides that "the Judges in every State shall be bound thereby, any thing in the Constitution or Laws of any State to the Contrary notwithstanding." Also, Article VI requires all members of the judiciary, state as well as federal, to take an oath "to support this Constitution ..."

\section{Judicial Review Against Congress}

In contrast to the unwillingness of the Supreme Court to serve as a unifying force in the administration of justice, Crosskey suggests that this characteristic shyness was not carried over with respect to the Court's assumption that it had the duty to pass upon the constitutionality of laws passed by Congress and the state legislatures. Instead, he argues, " . . . the Court has exercised far in excess of any, and power far different from any, it ever was intended to have, either by the Federal Convention which drew the Constitution, or by the American people who adopted it."24 The author thus squarely takes issue on this subject with the great weight of scholarship, criticising particularly Justice Frankfurter's views on the importance of judicial review by the Supreme Court. ${ }^{25}$

21311 U. S. 223 (1940).

22311 U.S. 169 (1940).

233 See Clark, State Law in the Federal Courts: The Brooding Omnipresence of Erie v. Tompkins, 55 YALE L. J. 267 (1946) and Gavit, States' Rights and Federal Procedure, 25 IND. L. J. 1 (1949).

24 2 CROSSKEY, at 938.

25 As set forth in Frankfurter, Distribution of Judicial Power Between United States and State Courts, 13 CoRnelr L. Q. 499, 503 (1928). 
Here again Crosskey takes us back to Blackstone, whose Commentaries found no place for a general power of this character in the courts, although Blackstone did recognize the established practice of the English judiciary of applying an equity of restraint to prevent the application of a statute to a particular set of facts. It is true, the author concedes, that in the 17 th century a concept of general judicial review began to develop to protect the royal dispensing power from Parliament, but he states that this beginning was wiped out by the Glorious Revolution of 1688 , which established the supremacy of Parliament over the Crown and its courts. In this context Crosskey argues that if the Convention had intended the Supreme Court to have the general power of judicial review, it would have said so in express terms as it did in other instances where the standing law was reformed.

Clearly there is no express power of this kind in the Constitution insofar as Congress is concerned, although the supremacy clause and Article III would appear to give the Supreme Court that authority with respect to the states. Certainly if the author is correct that Congress was given general legislative power, and that the states were subordinated to the national government, it would be an anomaly indeed for the Constitution to give the Supreme Court a veto power over Congress. Such a veto power makes sense only if it is assumed that the power of Congress was strictly limited to the enumerated powers. Even in this setting, it is very difficult to answer the question of why the Convention found it necessary to give the executive a limited veto power (since the King theoretically retained such a power), while failing to give the Supreme Court a fuller veto power (where it was not established under the standing law).

The conventional answer to this inquiry would be that there was no need to expressly mention judicial review, since there was no intention to limit the Supreme Court, while in the case of the President, it was intended to limit the veto power. Besides, the conventional argument goes, a general power of judicial review is to be implied from the Constitution, particularly from the "made in Pursuance" phrase of Article VI. But, argues Crosskey, since the supremacy clause expressly gave the Supreme Court general judicial review over state action, the failure to include a power of judicial review against Congress is a clear demonstration that no such power was intended under 18th Century rules of draftsmanship. This is still a good rule of construction today.

The orthodox argument in support of judicial review also is based upon the assumption that it existed in the colomies prior to the American Revolution. In this connection the author takes each of the cases relied upon, explains them in the greatest detail, and brilliantly whacks away at the claims that are made for each of them. (If the reader finds his evidence weaker with respect to a few of them, still one or two doubtful swallows 
do not make a summer.) Crosskey also takes issue with the contention of Beard and Corwin that Section 25 of the Judiciary Act of the First Congress reflected the Congressional understanding that the Supreme Court had been given a general power of review. It is in this setting that Crosskey points out that one of the judicial review proposals extant at Convention time was largely ignored, whereas the various other proposals of Madison to place some kind of legislative veto in the hands of the Supreme Court were specifically rejected on four occasions. How then, Crosskey asks, can it reasonably be concluded that the more sweeping judicial review against Congress reflected in the Dred Scott ${ }^{26}$ and subsequent cases was agreed upon by the Convention?

\section{Defense of the Judicial Prerogative}

After having mounted his attack .against judicial review, the author turns around and argues that the Supreme Court was given the authority to defend the judicial power against invasion by the other branches of government. The historical materials presented in connection with the judicial article clearly support the proposition that the Constitution was intended to free the judiciary from the executive, though the case for independence from Congress is less persuasive. Crosskey's own evidence is to the effect that English and Colomal judiciaries were coming more closely under the control of their respective legislatures. Moreover, the author refers to the authority given Congress to make rules of decision for the Supreme Court to follow. If Congress fully exercised this power, it is difficult to escape the conclusion that sooner or later the Supreme Court would decide that the judicial prerogative must be defended. Perhaps Crosskey would argue that the Congressional power to make rules of decision was intended to be so limited.

To Crosskey the judicial power which the Supreme Court may properly defend covers inore than that set forth in Article III. In addition, it includes the Eleventh Amendment, which is expressly directed to the Court, and the Fourth, Fifth, Sixth, Seventh, and Eighth Amendments, because "their substance makes clear that, as constitutional limitations, they must, nevertheless, be primarily applicable to the judicial branch of the government."2r Such a conclusion is not too comforting to those of us who are concerned with the role of the judiciary in enforcing some of the other amendments on which the liberties of a person depend..$^{28}$ Certain of these are discussed in Part $V$ of the work.

The argument for this limited kind of judicial review is based upon two

26. Dred Scott v. Sandford, 19 How. 393 (1857).

2T 2 CROSSREY, at 1004.

28 Compare Rostow, The Democratic Character of Judicial Review, 66 HARv. L. REv. 193 (1952). 
factors. The least important of these is the concession that the state cases which are cited as precedents for a general power of judicial review, at the most can be considered only as precedents for this limited power of judicial review. The other pillar for a judicial review narrowed to defense of the judicial power is the concept of the right of each branch of the government to interpret its own powers, rather than having them determined by the Supreme Court.

\section{Judicial Review and the Executive}

It is unfortunate that these volumes were in the hands of the printer before the decision in the Youngstown case, in which the Supreme Court asserted a power to review the President's seizure of the steel mills. However, Crosskey's views on this subject were stated in a debate with Professor Nathanson of Northwestern Umversity in an NBC broadcast on the University of Chicago Round Table program. ${ }^{29}$ Surprisingly enough, it was the latter who urged that "... it is not the function of the Supreme Court to keep him [the President] within the ends of his proper power." Crosskey's position was consistent with his argument in chapters 28 and 29. He said:

If these original ideas of the Federalist party, which was the party of the framers of the Constitution, were to be applied in this steel-seizure case, I would agree, of course, that the Court would be precluded from decision; [for] the case at issue involves the relations of the President and Congress. The Court's prerogatives and duties under the Constitution are in no way involved; and, if the original ideas were followed, I agree that the court would be without power to decide. The situation would be one for the House and Senate to handle under their powers of impeachement.

But then Crosskey went on to argue that since the Court had assumed the power of deciding constitutional questions involving Congress, it also was appropriate for it to perform the same function with respect to the President, particularly simce President Truman had agreed in advance to abide by the Court's decision. It is not clear to me whether Crosskey has by this indicated that he has given up hope that his views on judicial review will prevail, whether he simply wants to place the President on the same footing with Congress or whether his remarks were nothing nuore than a sharp reaction to the district court argument in which the government asserted unlimited Presidential powers. Perhaps some enterprismg law review will see fit to elicit from Crosskey a clarification of his views in this area.

\section{The Original Bill of Rights}

Part V, which is the final portion of these two volumes except for the previously discussed conclusion, is entitled "The Suprene Court and the

29 The transcript is available in a pamphlet entitled The Constitutionality of the President's Seizure of the Steel Industry, U. OF CHI. Round TABLE, No. 738, May 18, 1952, ten cents. 
Constitutional Limitations on State Governmental Authority" (chapters 30 through 32). Actually very little of this discussion is given over to state limitations in the original document, probably because they were partially mentioned in previous chapters. In chapter 30 the emphasis is upon Amendments II to VIII, and the remaining chapters are devoted to the 14th Amendment.

At the outset it is pertinent to refer to the relationship Crosskey sees between the Supreme Court's construction of the state limitations and the development of the power of Congress. If, as Crosskey contends, the Supreme Court permitted the states to ignore the limitations placed upon them by the original Constitution and the early amendments, while at the same time applying these limitations against Congress, then the states were given a mobility to govern which Congress did not possess. Particularly since this mobility was described as the "police power" of the states, it was easy for the notion to grow that Congres did not possess a power of internal police. Coupled with the fact that Congress was not to enter the sphere of economic regulation until the passage of the Interstate Commerce Act in 1887 , it was easy for the community to accept the concept of a national government of limited powers.

The nub of Crosskey's position is that, contrary to the decision in Barron v. Baltimore, ${ }^{30}$ most of the limitations in the Bill of Rights were, from the beginning, applicable against the states as well as against Congress. The only exceptions were the First Amendment, which was directed against Congress expressly, and that part of the Seventh Amendment relating to appeals in the Federal courts. In fact, these exceptions are the most obvious piece of evidence that the limitations in the remainder of the Bill of Rights were to be applicable to every governmental unit. The most siguificant supporting piece of legislative history for Crosskey's view is that Madison originally presented most of the amendments for insertion in Section 9 of Article I of the Constitution, but that this course was rejected. This is crucial because Section 9 contains the various limitations on the national power. The fact that the Senate subsequently voted down an Amendinent paralleling the First Amendment and applicable only to the states, frequently regarded as evidence in support of the Barron case, is viewed by Crosskey as simply destroying the basis for an inference that the amendinents were applicable only to the nation.

The author does not stop here, however, for in connection with his discussion of the Fourteenth Amendinent he convincingly demonstrates that by the "privileges and immunities" clause Thaddeus Stevens and his allies intended not only to overrule the Barron case, but in addition to

30 ๆ Pet. 243 (1833). 
make the First and Seventh Amendments applicable against the states too. Since the work contains evidence which was not available to Justice Black in his attempts to give the "privileges and immunities" clause this meaning, undoubtedly the next appropriate case on this subject will find the issue raised anew by counsel. Even if the Crosskey work alone is insufficient to provoke new arguments among the scholars, that next case will be responsible for more articles than was Adamson v. California. ${ }^{31}$

We are living in times of great concern over the extent of the protection the First Amendment affords. The Spring issue of the University of Chicago Law Review contains three important articles on the subject. ${ }^{32}$ For our purposes here the most relevant one is by Malcolm P. Sharp, a colleague and friend of Crosskey's, a man who has long understood the significance of Crosskey's research when some others were inclined to deride it. While taking an opposite side from Professor Swisher with respect to the general character of the Crosskey contribution, he indicates serious concern over the impact the work will have on the defense of civil liberties, particularly in connection with the First Amendment. The reason for this is that Crosskey's construction of Article VI would permit the Supreme Court to invalidate state action inconsistent with the First Amendment. Yet Congressional violation, in view of his rejection of a power of general judicial review, " . . . can be safeguarded . . . only by the intelligence and self-restraint of Representatives and Senators themselves."133

Sharp feels that some way must be found to permit judicial review of Congressional action which involves the First Amendment. This is not to say that he approves of Justice Frankfurter's construction of the First Amendment, ${ }^{34}$ for he certainly does not. In fact, he thinks the Court's present view of the First Amendment "may mark the end of effective judicial safeguards for freedoms of this type" and has the same practical effect as Crosskey's view. (Considering the number of arrows that dart toward Frankfurter in this work, the Justice will be amused to find himself placed in the same boat with Crosskey.) What Sharp wants is to have the First Amendment construed in the manner of Justice Harlan and Alexander Meiklejohn, but at the same time have a Supreme Court that will enforce it against Congress. Since Crosskey does concede the Court the

31332 U. S. 46 (1947). Compare especially Fairman, Does the Fourteenth Amendment Incorporate the Bill of Rights? The Original Understanding, 2 STAN. L. REv. 5 (1949), Morrison, The Judicial Interpretation, 2 StaN. L. Rev. 140; see also Frank and Munro, The Original Understanding of "Equal Protection of the Laws," 50 Cor. L. REv. 131 (1950).

${ }^{32} \mathrm{Katz}$, Freedom of Religion and State Neutrality, 20 U. of Chr. L. REv. 426 (1953); Meiklejohn, What Does the First Amendment Mean?, 20 U. of CEr. L. Rev. 461 (1953); and Sharp, The Old Constitution, 20 U. of Cwr. L. Rev. 529 (1953).

${ }^{33}$ Id. at 531 .

34 Dennis v. United States, 341 U. S. 494 (1951) (concurring opinion). 
right to protect the judicial prerogative through the judicial review, Sharp suggests that the freedoms of the First Amendment might well be classified among the things the Court may legitimately protect. It is certainly possible for the Court to adopt such a theory without doing violence to the main outlines of the Crosskey thesis.

\section{The Fourteenth Amendment}

The author's view of the "privileges and immunities" clause of the Fourteenth Amendment has been set forth above. There remain for discussion his views of the "due process" and "equal protection" clauses of that Amendment.

In the setting of his views about the general legislative power of Congress, Crosskey would be expected to reject "substantive" due process as he does. The interesting thing about his argument is the scope to be given "due process," in the Fifth as well as the Fourteenth Amendment. Instead of arguing that the Fourteenth Amedment guaranteed to citizens the general procedural protections extant in 1868, the author argues that the Fourteenth's "due process" clause was designed to protect both citizens and aliens alike from state action which (1) was inconsistent with the procedural guarantees of the common law of 1791, or the common law as amended by statute, or which (2) violated any of the procedural protections found in the Constitution itself.

It is not an overstatement to say that Crosskey is bitter over the decisions in which the Court began to build up "substantive" due process while simultaneously ignoring the procedural protections which he feels the Fourteenth Amendment was designed to erect against the states. At some length he records the Court's development of the use of "substantive" due process against the states, and finally its use against Congress. In this twisting he shows the Court substituting its judgment for that of the legislatures, first by declaring the statute before it "not a law" and subsequently saying the law lacked "due process." This, says Crosskey, amounted to a test of what is "due law," rather than what is "due process."

Similarly the author heaps scorn upon the construction which has been given the "equal protection" clause, starting with the Slaughter-House Cases, ${ }^{25}$ a scant five years after the adoption of the Fourteenth Amendment. As he does in connection with the other crucial portions of the Fourteenth Amendment, Crosskey draws on the great historical controversy produced by the Dred Scott decision. Here, the reader is reminded, Chief Justice Taney found that when a citizen of one state moved into another he lost his rights. The Fourteenth Amendment was passed to insure that no state would "deny to any person, within its jurisdiction, the equal pro-

3516 Wall. 36 (1873). 
tection of the laws." This clause was designed to require a state to make available the same protections to all persons, and to prevent any state or state official from pursuing any inter-personal discrimination. In Crosskey's view, such things as the reasonableness of the classification of business, economic activity, etc., were not covered by the "equal protection" clause. This limited application of the clause appears to be dictated principally because of his fear that permitting the Court to so apply it would lead to but another form of "substantive" due process.

One senses that Crosskey feels that the Justices, from north as well as south, conspired to read out of the Constitution the amendment which climaxed the victory of the nationalists of the Civil War and Reconstruction. He feels that this development was deliberate, as the Amendment was so recent and there were no problems of changed word meanings as with respect to the original docunent. But it is possible that the northern justices only reflected the development of a new pro-southern national bias which followed Reconstruction, demonstrated by the resentment against Thaddeus Stevens and other Republican Radicals, and the pressure to pull the occupation armies out of the southern states which was involved in the settlement over the Hayes-Tilden election. Myrdal has noted significantly that ever since 1870 a pro-southern bias has extended to northern writers on social problems. ${ }^{36}$

\section{Further Comments}

There are other important things in Crosskey which are not discussed here because of the limitations of space, the full faith and credit clause of Article IV, to give but one example. The reader will want to pore over the entire work in any event. Not only are the arguments and pieces of evidence new and fascinating, but so is the style. The author seems to have absorbed not only the ideas of the late 18th century, but a good deal of its phraseology and sentence structure as well. This helps to carry one back to the days of the Convention and with inany people will buttress the thesis of the work.

The chapters are written with a goodly amount of verve, spice, and sarcasm. It is this biting sarcasm that may drive a great many people away from the book. Were not the contributions it contains so startling and the argument so powerful it might be quickly rejected for its subjectivity. However, the sarcasm serves a very real function here; it cuts so savagely in many places that many will be liurt, but none can forget.

${ }^{30}$ A pro-southern bias, is, however, not restricted to Southern writers. Ever since the great national compromise of the 1870's, when Reconstruction was liquidated, the need for rationaljzation of the anomalous position and treatment of the Negro has been national in scope. Contrary to the belief commonly held in the South, the present writer has reached the conviction that not only the general public in the North but also Northern social scientists are rather pro-

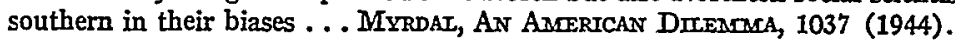


It will be interesting to watch the process by which the Crosskey thesis becomes accepted, as much of it is certain to be. The express recognition of a comprehensive commerce power in Congress will in all probability come first, as only the bones of the "interstate" theory remain. The overruling of the Erie doctrine should not be far away, for in this instance there are probably more factors (such as the opportunity for the Supreme Court to enhance its own powers) favoring the Crosskey position than against it. The abandonment by the Supreme Court of judicial review against Congress may never come about, although its use has become quite limited in recent years. Yet there are very strong forces in the community which will never yield on judicial review, including both proponents of civil liberties and defenders of established economic arrangements. It would take a greater emotional sweep than has now seized the white population of South Africa $^{3 r}$ to dislodge this judicial power in America, for here the tradition is deeply embedded, particularly among lawyers who have asumed it as Holy Writ from the beginning of their careers.

In terms of its legal analysis lawyers will recognize Crosskey's relationship to the efforts of Charles A. Beard in his Economic Interpretation of the Constitution of the United States, which was once considered a controversial book, until its author turned his work in more orthodox directions. With respect to the commerce power, Hamilton and Adair's little book entitled The Power to Govern will be recognized as another ancestor. In terms of methodology, social scientists will see Crosskey's kinship with the Schlesingers, with Gilbert Barnes, and with Vernon L. Parrington, although Crosskey undoubtedly regards the latter's efforts (in Main Currents in American Thought) to establish Jefferson as the "great man" of our history as inimical to his construction of the Constitution.

By this work Crosskey has established the strongest possible statement as to the original meaming of the Constitution. This will be debated by some, but the strongest defense of orthodox theories will be that the Constitution means what the commumity today believes it does. As Professor Swisher argues, ${ }^{38}$

... If a few people in the Constitutional Convention planned the centralization of power the author envisages, the American people quickly demonstrated they wanted something very different ...

No amount of rewriting of history can change this fact. If the Framers really attempted to palm off on the people something that might easily become a highly centralized tyranny-and this the reviewer profoundly

37 See the comments by Griswold, The "Coloured Vote Case" in South Africa, 65 HaRv. L. Rev. 1361 (1952), and The Demise of the High Court of Parliament in South Africa, 66 HARv. L. REv. 864 (1953).

3s Supra note 2. 
disbelieves-more than a century and a half of American history demonstrates that the people will have none of it.

And as if anticipating this thrust Crosskey sarcastically comments: ${ }^{39}$

... The actual provisions of the historic document relating to Congress' powers ... are deemed by these learned men (the scholars) to be without importance, except as the mere starting point of a magnificent development, still going on, with-which the Court ... . ought by no means to interfere, but, rather, promote by every means that lies within - or indeed, without-its power ...

It is here that the main issue will be jomed. And it will not necessarily be decided against Crosskey, for there are good arguments on his side, arguments touching upon the existence of the amending process, arguments about Anglo-American traditions of contract, arguments growing out of the function of a Constitution in establishing the legitimacy of government in the absence of a Crown, and the umiversal acceptance in this country of the Constitution as a higher law, a view encouraged, incidentally, by the concept of general judicial review to which Crosskey takes exception.

This work will bring both heat, light, and confusion to the controversy between the adherents of the "written Constitution" and the "living" or "growing Constitution." The proponents of the former have long fought the tendency toward centralized government, and have used their assumptions about the limited power of the written Constitution as one of their weapons. Now, if Crosskey gains acceptance, they will find the "written Constitution" being used against them and will beat a hasty retreat to the "growing Constitution," for disproving Crosskey in any other way is a formidable and perhaps an impossible task. As the disciples of Brandeis are thus so strangely augmented, a new movement will begin in the other direction. The proponents of effective government from Washington will dispense with the "growing Constitution" and find new reason for the glorification of Justice Harlan.

By and large the legal community will find comfort or distaste in Crosskey depending upon their own biases about the issue of Big Government. The one exception to this will be the financial community and its representatives, who will probably be willing to swallow their fear of Big Government in exchange for Federal commercial laws. The political scientists and historians are nore likely to present uniform opposition than the lawyers. At the outset, this group is not likely to be interested in either the word constructions or the evidence of Constitutional history which support the Crosskey thesis. Too many of this group are wedded to concepts to which the author pays little lieed. Moreover, to some extent a portion of

392 Crosskey, at 1171. 
this group have as their raison d'etre the complicated system of state-federal relations that have grown out of the Supreme Court's limitation of the commerce power and the evolution of the dual judicial system. Not only does Crosskey threaten their bread and butter, but in addition he would shatter their pride by placing in question the basic assumptions on whicl their writing and teaching is built. But fortunately or unfortunately, depending upon one's point of view, the political scientists have little effect upon the court of Constitutional law and history, as they seldom legislate, prepare briefs, or argue cases.

One of the distinguished members of this group, Professor Allan Nevins of Columbia, recently has published a review of Crosskey which reflects some of these biases. ${ }^{40}$ But it must be conceded to Mr. Nevins that his attempt at ridicule is a very effective one. Thus he likens Crosskey's efforts to that of a geographer who describes what would have happened to the development of the country if the Mississippi River had run from east to west! This can be somewhat accurately described as the "if my grandmother had been a cable car" argument. But the Constitution is neither a river nor a cable car, and clever analogies with respect to a commentary about the Constitution cannot for long avoid the serious discussion the current work deserves.

Among the lawyers, there is a great danger that some of the more serious proponents of the "growing constitution" (not the new conservative converts) will respond to Crosskey's attacks upon them by failing to realize that this contribution is itself a new vehicle by which government on this continent can be made more orderly and more effective. I would have preferred it if Crosskey sincerely had agreed that such persons as Holmes and Brandeis had shown real genius in developing concepts under which first the states, then the nation, were given the power to govern. In the times and setting in which it was necessary for their contribution to be made, there was no Crosskey before them, and the economic and political conditions and institutions which would make these volumes acceptable did not arise until 1933.

But is Crosskey's Constitution the kind of Constitution that is the most desirable and useful? Messrs. Swisher and Nevins are greatly concerned that it will promote a centralized tyranny, and no doubt a great many other reviewers will follow suit. But there is another facet which deserves attention, namely, does the Crosskey construction-or any other construction for that inatter-lend itself to the mobility of foreign policy and to the capacity to defend the nation which the world situation appears to require? It seems to this writer that the imaginative use of the executive power to

${ }_{40}$ N. Y. Times Book Review, May 31, 1953, at 7. 
recommend legislation provides most, if not all, the flexibility that is required. One who is potentially both the nation's "first legislator" as well as its administrator operates from a position of real power. In any event, this seems like a more timely and current debate than the one over states rights which Crosskey's first reviewers have announced. 